\title{
An add-on therapy for neuropathic pain: Infiltration block with diclofenac sodium and lidocaine through the hypertrophic scar tissue
}

\author{
Nöropatik ağrı için ek tedavi uygulaması: Hipertrofik skar dokusuna diklofenak sodyum \\ ve lidokain ile infiltrasyon bloğu
}

(1) Hatice Evren EKER, (1) Oya YALÇIN ÇOK, @ Nesrin BOZDOĞAN ÖZYILKAN, @ Anış ARIBOĞAN

\begin{abstract}
Summary
In some situations, the cause of the supposed neuropathic pain might be related to abnormal tissue recovery such as scar formation due to wound retraction that might create mechanical compression on the nerve tissue. In this report we describe infiltration block with diclofenac sodium and lidocaine through the hypertrophic scar tissue to reduce mechanical stress in 3 patients. The infiltration technique might resolve the tension of the contracted scar tissue by tearing the adhesions and the eliminated mechanical compression would reduce the pressure on nerve tissue and hence neuropathic pain symptoms.
\end{abstract}

Keywords: Diclofenac sodium; infiltration block; lidocaine; neuropathic pain.

\begin{abstract}
Özet
Bazı durumlarda öngörülen nöropatik ağrı nedeni sinir dokusunda mekanik kompresyona neden olan yara büzüşmesine bağlı skar oluşumundaki gibi anormal doku iyileşmesi olabilir. Bu yazıda mekanik stresi azaltmak için hipertrofik skar dokusu içine diklofenak sodyum ve lidokain ile infiltrasyon bloğu uyguladığımız 3 hasta sunulmaktadır. İnfiltrasyon tekniği yapışıklıkların ayrılmasını sağlayarak kontrakte skar dokusundaki gerginliği ortadan kaldırabilir ve mekanik kompresyonun giderilmesi sinir dokusu üzerindeki basıncı ve bundan dolayı nöropatik ağrı semptomlarını azaltabilir.
\end{abstract}

Anahtar sözcükler: Diklofenak sodyum; infiltrasyon bloğu; lidokain; nöropatik ağrı.

\section{Introduction}

The main causes of neuropathic pain include inflammatory and non-inflammatory conditions such as infection, trauma, metabolic abnormalities, chemotherapy, surgery, irradiation, neurotoxins, nerve compression, inflammation, and tumor infiltration. Through the secondary factors clinical recovery would only be concluded by creating the true aetiology. For instance, the neuropathic symptoms might be due to the pressure on peripheral nerves originating from painful hypertrophic scars which were closed by a great tension. ${ }^{[1]}$ In this situation, the inflammatory response generated from damaged nociceptors in scar areas accompanied by excessive fibrosis might be the source of neuropathic scar pain. ${ }^{[2]}$
There are various modalities of treatment for neuropathic pain but the exact mechanism of symptoms should be distinguished to improve the patient outcome. Treatment strategies for neuropathic pain secondary to scar tissue would be managed by suppressing inflammation and fibroblast activity through the scar tissue. Inflamed tissue are frequently sensitive to non-steroid anti-inflammatory agents and the mechanism depends on inhibiting the production of inflammatory mediators and fibroblast modulators like PGE2 and TGF- $\beta{ }^{\left[{ }^{[3]}\right.}$ The elimination of mechanical compression of the hypertrophic scar tissue by inhibiting inflammatory response and the release of cytokines would reduce the pressure on nerve tissue. In this report, an infiltration block with diclofenac

The first case was presented at the $9^{\text {th }}$ Congress of the European Pain Federation in Vienna, Austria, 2015 and the second case was presented at the $34^{\text {th }}$ Annual ESRA Congress in Ljubljana, Slovenia, 2015.

Department of Anesthesiology and Reanimation, Başkent University Faculty of Medicine, Adana, Turkey

Submitted: 12.04.2016 Accepted after revision: 23.06.2017 Available online date: 13.12.2018

Correspondence: Dr. Hatice Evren Eker. Dadaloğlu Mah., 36 Sok., No: 9, Yüreğir 01250, Adana, Türkiye.

Phone: +90 - 505 - 7482038 e-mail: evreneker@yahoo.com

(c) 2019 Turkish Society of Algology 
sodium $100 \mathrm{mg}$ and lidocaine $0.5 \%$ injection through the hypertrophic scar tissue was described to reduce tension of the contracted tissue, the mechanical stress on peripheral nerves and secondary neuropathic pain symptoms.

\section{Case Report}

Case 1 - A 35 years old man who had femoral artery injury due to a gunshot and femoral artery repair with stent grafting complained of burning, tingling, shooting, stabbing and stretching on his left leg. Physical examination revealed hypoesthesia and motor weakness. Electromyography demonstrated axonal degeneration of tibial and peroneal branches of sciatic nerve at the femoral level. The initial NRS was 10 and decreased to 6 after medical therapy and caudal steroid injection. The pain and sensory symptoms were no longer present at sciatic nerve dermatomes but burning sensation extending from frontal leg to toes did not recover. Re-examination revealed increased burning sensation after palpating the scar tissue with pressure. The stiffness of the scar tissue was also determined by palpation and palpation of the scar lead to phantom pain sensations in a dermatomal distribution. Add-on therapy was performed with fan-like infiltration of $100 \mathrm{mg}$ diclofenac sodium and $50 \mathrm{mg} 0.5 \%$ lidocaine in $10 \mathrm{~mL}$ saline solution through the scar tissue (Fig. 1). The infiltration block was repeated for 3 times with one week intervals. In each assessment, progressive decrease in stiffness was formed and the tension and contraction of the scar tissue which were determined by palpation were decreased. The patient recovered from pain and burning sensation during a 12-week follow-up.

Case 2 - A 37 years old man developed post-amputation pain due to a traffic accident a year ago. Mirror therapy and medical therapy with pregabalin for phantom pain failed. The complaints like burning, tingling, shooting, stabbing and stretching were

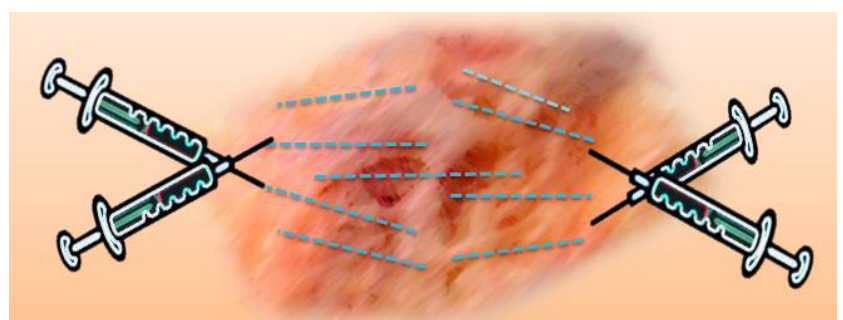

Figure 1. The illustration of the infiltration technique in the hypertropic scar formation. increased following placement of prosthesis on his left leg. Physical examination revealed increasing pain during palpation of hypertrophic scar tissue on the stump and leading to phantom pain sensation in a dermatomal distribution. Medical therapy with tramadol 2x10 drops/daily and infiltration block through the contracted scar tissue with $100 \mathrm{mg}$ diclofenac sodium and $50 \mathrm{mg} 0.5 \%$ lidocaine in $10 \mathrm{~mL}$ saline solution decreased the initial NRS score of 10 to 4 , after 2 repeats with one week interval. One week after the first injection, pain complaints related to placement of prosthesis were decreased and following the second infiltration the patient substantially healed from limb pain and phantom sensations during an 8-week follow-up.

Case 3 - A 68 years old woman who underwent two subsequent carpal tunnel surgery 1.5 years ago had a claw hand with scar tissue starting from wrist up to the middle of the palm. She became completely unable to move her fingers and did not allow the affected hand to be touched though complaining of burning, shooting, stabbing like pain with numbness at her fingers. The symptoms accompanied with allodinia and hyperalgesia. Medical therapy with tramadol $3 \times 10$ drops/daily, pregabalin $2 \times 150 \mathrm{mg}$ and duloxetine $1 \times 30 \mathrm{mg}$ treated her radiating pain to the elbow. However, other complaints persisted and infiltration block at the pervasion site of the contracted scar tissue at the hand with $100 \mathrm{mg}$ diclofenac sodium and $50 \mathrm{mg} 0.5 \%$ lidocaine in $10 \mathrm{~mL}$ solution decreased the initial NRS score of 8 to 2 following 4 repeats with one week interval. But the limitation of movement in the hand fingers improved after 2 repeats. The size of the scar tissue was restricted and the tension was decreased during a 9 week follow-up.

\section{Discussion}

Neuropathic pain often requires a combination of medical and interventional treatment and may respond well to novel approaches. In case of persistent pain with lack of a cure, etiology of pain should be re-evaluated for the rescue symptoms and ongoing causes. In our cases above, limited efficacy with specified medications and interventional treatments for neuropathic pain were achieved. The patients were re-examined by palpating the scar tissue. It was observed that neuropathic symptoms and interestingly phantom sensation in the second patient were trig- 
gered. We thought that the cause of the supposed neuropathic pain and phantom sensation might be related to abnormal tissue recovery such as scar formation due to wound retraction and poorly fitting prosthesis respectively and both were created by mechanical compression on the nerve tissue.

The lymphocytes, mast cells and cytokines play a vital role in the acute and chronic inflammatory responses that drive fibrosis in injured tissues. The inflammatory process can become deregulated resulting in pathological wound repair, accumulation of permanent fibrotic scar tissue when the fibroblasts produce excessive and irregular extracellular matrix. ${ }^{[4]}$

The accumulation of collagens excreted from fibroblasts may cause excessive fibrosis and wound retraction and influence the release of epidermal derived cytokines (IL-1a, TNF- $a$ ), dermal-derived inflammatory mediators and TGF- $\beta .^{[3]}$

Scars can cause many problems such as limited joint mobility, growth impairment and loss of normal skin functions. ${ }^{[5]}$ Rarely, the tension of the scar tissues might be the cause of neuropathic pain symptoms. Hypertrophic scar tissues are under the influence of multiple vector forces in general and the increased production of collagen supports the scar tissue to resist these vectors. The strained scar tissue localization, the tissue stiffness and its rebound effect on nerve tissue might be the cause of neuropathic pain indirectly. The exact mechanism, hence the treatment of choice might depend on the nature of the scar.

Eventually, the contracted tissue might induce persistent pain with components of hyperalgesia and allodynia referred to the distribution of the crushed nerve and contribute to extrinsic neuropathic pain sensations. Also nociceptors have a rich variety of immune receptors and evidence exists for roles of IL-1 $\beta$, IL-6, TNFa, bradykinin, and prostanoids. Sensitization has also been reported in the intact nociceptors with an increased sensitivity to TNF-a, and allodinia may be present even with loss of C-fiber innervations of the epidermis. ${ }^{[1,6]}$

In terms of pharmacological anti-fibrosis, steroid injections are established to reduce inflammation, collagen synthesis and fibroblast proliferation of hypertrophic scars. ${ }^{[4]}$ However, injection is painful and the lesions continue to grow once injections are stopped. Alternative immune suppressive agents have also been used to counter skin fibrosis but their use is quite limited. ${ }^{[7]}$ In this report, an infiltration block with a non-steroid anti-inflammatory agent and a sodiumchannel blocker was preferred to reduce inflammation and collagen formation although controversies for non-steroid anti-inflammatory agents on the wound healing are present. ${ }^{[3,8]}$ Also clinical experimental data suggest that changes in expression of sodium-channel isoforms are involved in chronic inflammatory pain. ${ }^{[9]}$ It is hypothesized that lidocaine alleviates pain by reducing or preventing damaged primary sensory neurons from excessive discharges through the blockade of sodium channel activity. ${ }^{[10]}$ The synergistic effect of diclofenac sodium and lidocaine on inflammation, radiation of the solution through the layers of the scar tissue due to fan-like infiltration and the volume effect of the solution was expected to tear the adhesions and resolve the tension of the contracted scar tissue. Eventually, the improved responses of our cases for 8 to 12 week period support the argument.

Physicians keep in mind that phantom sensation distal to hypertrophic scar tissue should be carefully evaluated and differentiated for a proper treatment. In this report we presented three patients with persistent neuropathic pain symptoms that subsequently discovered to be due to contracted, painful hypertrophic scar tissue which continued after the novel medications of neuropathic pain. Our focal point with our patients above was treating neuropathic symptoms by suppressing inflammation, tearing adhesions and resolving tension of the contracted scar tissue by infiltrating and tunneling through the scar tissue by a non-steroid anti-inflammatory agent with lidocaine. Consequently, we suggest that regional treatment with $100 \mathrm{mg}$ diclofenac sodium and 50 $\mathrm{mg} 0.5 \%$ lidocaine at scar site may be an alternative management option in patients suffering from posttraumatic neuropathic symptoms.

Informed consent: Written informed consent was obtained from the patient for the publication of the case report and the accompanying images.

Conflict-of-interest issues regarding the authorship or article: None declared.

Peer-rewiew: Externally peer-reviewed. 


\section{References}

1. Campbell JN, Meyer RA. Mechanisms of neuropathic pain. Pain 2006;52(1):77-92.

2. Aarabi S, Longaker MT, Gurtner GC. Hypertrophic scar formation following burns and trauma: New approaches to treatment. PLoS Med 2007;4(9):e234.

3. Sandulache VC, Parekh A, Li-Korotky H, Dohar JE, Hebda PA. Prostaglandin E2 inhibition of keloid fibroblast migration, contraction, and transforming growth factor (TGF)$\beta 1$-induced collagen synthesis. Wound Repair Regen 2007;15(1):122-33.

4. Shaw TJ, Kishi K, Mori R. Wound-associated skin fibrosis: mechanisms and treatments based on modulating the inflammatory response. Endocr Metab Immune Disord Drug Targets 2010;10(4):320-30.

5. Wilgus TA, Wulff BC. The Importance of Mast Cells in Dermal Scarring. Adv Wound Care (New Rochelle)
2014;3(4):356-65.

6. Schäfers M, Lee DH, Brors D, Yaksh TL, Sorkin LS. Increased sensitivity of injured and adjacent uninjured rat primary sensory neurons to exogenous tumor necrosis factor-alpha after spinal nerve ligation. J Neurosci 2003;23(7):3028-38.

7. Juckett G, Hartman-Adams H. Management of keloids and hypertrophic scars. Am Fam Physician 2009;80(3):253-60.

8. Winter GD. Some factors affecting skin and wound healing. J Tissue Viability 2006;16(2):20-3.

9. Amir R, Argoff CE, Bennett GJ, Cummins TR, Durieux ME, Gerner $\mathrm{P}$, et al. The role of sodium channels in chronic inflammatory and neuropathic pain. J Pain 2006;7(5 Suppl 3):S1-29.

10. Zhang JM, Li H, Munir MA. Decreasing sympathetic sprouting in pathologic sensory ganglia: A new mechanism for treating neuropathic pain using lidocaine. Pain 2004;109(12):143-9. 